\title{
Multidose Container with Metering Pump
}

National Cancer Institute

\section{Source}

National Cancer Institute. Multidose Container with Metering Pump. NCI Thesaurus.

Code C149672.

Multidose container with integral metering pump. 